\title{
RESEARCH OF THE RHYTHMICAL ABILITIES OF SPORTS STUDENTS
}

INVESTIGACIÓN DE LAS HABILIDADES RÍTMICAS DE LOS ESTUDIANTES DE DEPORTE

PESQUISA DAS HABILIDADES RÍTMICAS DE ESTUDANTES DE ESPORTES

Giurka Gantcheva, $P h D^{1}$

Abstract

The elaborateness of motor activities in sports disciplines increases the requirements to agility being a complex quality of athletes. The different components of this quality, defined as the ability for quick change in the execution of movements and abilities for reaction in various conditions, are in complex interrelation. Object of the research is the rhythmical abilities of students at the three faculties of the National Sports Academy - Coach faculty, Physical education faculty, and Kinesitherapy faculty. In order to assess the coordination in rhythm we used four tests of Damjanovska, Gontarev, Rhedzepi, and Gantcheva (2015). The results from the research show that the students in the three faculties possess good rhythmical abilities. The sports practiced with musical accompaniment facilitate the harmonious mastery of coordination in rhythm.

Keywords: coordination, rhythmical abilities, sport, students

\section{Resumen}

La elaboración de actividades motoras en las disciplinas deportivas aumenta los requisitos para que la agilidad sea una cualidad compleja de los atletas. Los diferentes componentes de esta cualidad, definida como la capacidad de cambio rápido en la ejecución de movimientos y habilidades de reacción en diversas condiciones, se encuentran en una interrelación compleja. El objeto de la investigación es la capacidad rítmica de los estudiantes en las tres facultades de la Academia Nacional de Deportes: facultad de educación superior, facultad de educación física y facultad de kinesioterapia. Para evaluar la coordinación en el ritmo utilizamos cuatro pruebas de Damjanovska, Gontarev, Rhedzepi y Gantcheva (2015). Los resultados de la investigación muestran que los estudiantes en las tres facultades poseen buenas habilidades rítmicas. Los deportes practicados con acompañamiento musical facilitan el dominio armónico de la coordinación en el ritmo.

Palabras clave: coordinación; habilidades rítmicas; deporte; estudiantes

1 Full Professor, National Sports Academy „Vassil Levski“, Gymnastics Department. Sofia, Bulgaria. giurka@abv.bg 


\section{Resumo}

0 desenvolvimento de atividades motoras em disciplinas esportivas aumenta os requisitos para que a agilidade seja uma qualidade complexa dos atletas. Os diferentes componentes dessa qualidade, definida como a capacidade de mudança rápida na execução de movimentos e capacidades de reação em diferentes condições, estão em uma inter-relação complexa. 0 objeto da pesquisa é a capacidade rítmica dos alunos nas três faculdades da Academia Nacional de Esportes: faculdade de ensino superior, faculdade de educação física e faculdade de cinesioterapia. Para avaliar a coordenação no ritmo, foram utilizados quatro testes de Damjanovska, Gontarev, Rhedzepi e Gantcheva (2015). Os resultados da pesquisa mostram que os alunos nas três faculdades possuem boas habilidades rítmicas. Os esportes praticados com acompanhamento musical facilitam o domínio harmonioso da coordenação no ritmo.

Palavras-chave: coordenação; habilidades rítmicas; esportes estudantis

Fecha de recepción: 2 de mayo de 2018

Fecha de aceptación: 10 de septiembre de 2018

Para citar este artículo:

Gantcheva, G. (2018). Research of the Rhythmical Abilities of Sports Students. Lúdica Pedagógica, 27, x-xx. 


\section{INTRODUCTION}

The National Sports Academy "Vassil Levski" in Sofia is the only sports university of this kind in Bulgaria. This year it celebrates its 75th anniversary and is proud of its students - a pleiad of Olympic, World and European champions, high-level coaches, and specialists working all over the world. The education of the students is differentiated into three main faculties and one department (See figure 1).

The future coaches in 56 kinds of sports are educated in the Coach faculty. The future physical education teachers in all degrees of school education study in the Physical education faculty. The future kinesitherapy specialists and those who will work in the field of tourism and sports animation are in the third faculty.

The students have practiced or continue to practice different kinds of sports and have achieved success during their sports career. The curriculum includes theoretical subjects and practical activities in the main sports disciplines - athletics, swimming, gym- nastics and sports games, skiing, folklore dances, as well as many other sports. The number of lectures and practical activities, as well as their ratio, is determined depending on the specifics of the subject and is dependent on the requirements of the faculty. The future physical education teachers study different kinds of exercises taken from various sports with levels of difficulty accessible for the pupils of different grades - primary education (from $1^{\text {st }}$ to $4^{\text {th }}$ grade), secondary education (from $5^{\text {th }}$ to $8^{\text {th }}$ grade) and high schools (from $9^{\text {th }}$ to $12^{\text {th }}$ grade). The future coaches study the basic subjects and deepen their knowledge in the field of the sport they have chosen (e.g. football coach, gymnastics coach, swimming coach). The future kinesitherapists are taught in such a way that they will be able to use the exercises taken from different sports in their work with ill people and people with specific needs.

Their successful performance in the motor activity practiced by them depends on several factors and to a great extent on the level of their physical qualities.

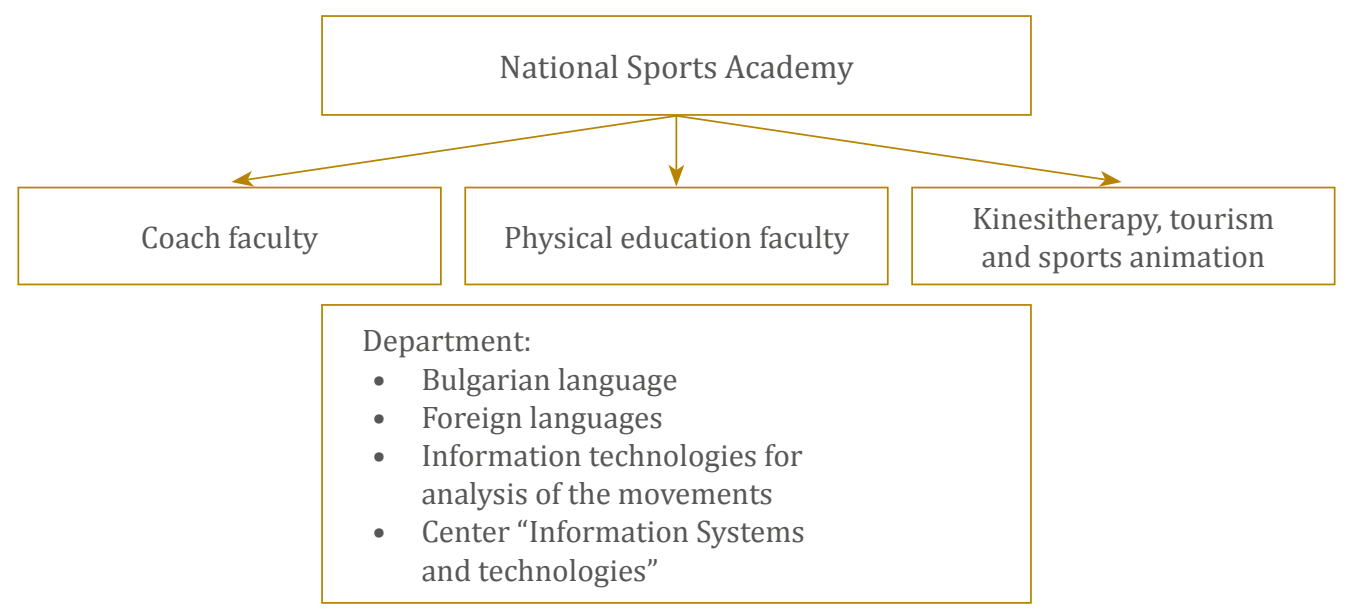

Figure 1. Faculties at National Sports Academy.

Modern sport is characterized by its complexity of motor movements. Certain physical qualities dominate in the different kinds of sports. Agility, being a complex quality, finds much more application and is in close relation to coordination, which is defined as ability for quick change in the performance of movements according to the ability to execute fast, coordinated and connected movements (Damjanovska, Gontarev, and Radisavljevic, 2013; Damjanovska et al., 2015).

Some authors consider agility the most important complex motor quality dependent on the achieved potential of strength, speed and flexibility, and also requires the manifestation of abilities for reaction in different conditions (Stoikov, 2014). Other authors (Mienel and Schnabell, 1987; Rachev, 1984) define coordination abilities as related to rhythmical abilities.

We generally agree with the opinion of the cited authors; however, it does not apply to an equal extent to all kinds of sports. They do not take into consideration some factors typical of what is known as artistic disciplines (rhythmic gymnastics, aesthetic gymnastics, figure skating, and synchronized swim- 
ming) where the use of musical accompaniment is obligatory and determines the execution of motor actions. The above-mentioned rhythmical abilities and abilities for reaction are part of the components of coordination abilities (Hadjiev, Andonov, Dobrev, and Petrov, 2011).

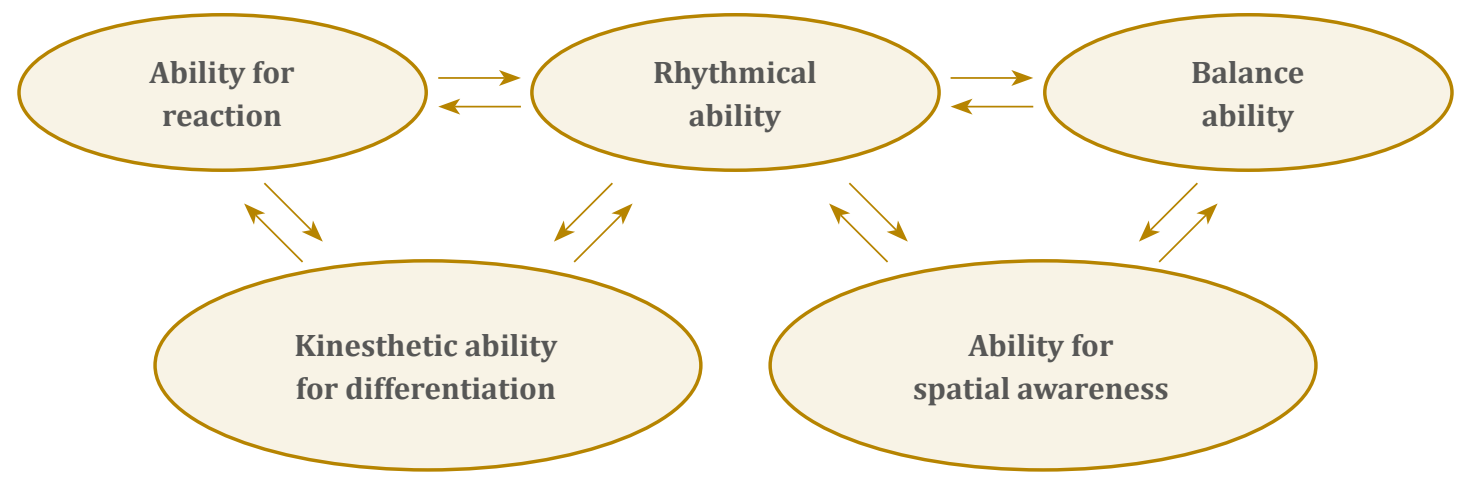

Figure 2. Components of coordination abilities in gymnastics.

Rhythm often means the way of unifying the rhythms between a person and a melody or a moving object and a person (Schaal, Sternad, Osu, and Kawato, 2004). The rhythmical ability manifests to a greater extent in artistic disciplines where the execution is accompanied with music and the unison between the rhythm of the movements and the rhythm of the music is obligatory, both for the artistic perception of the routines and for the competitive rules and regulations for evaluating technical performance. In other sports, from the evaluation's point of view during competition, this is not mandatory, but rhythm is present in all human activities (Zachopoulou, Tsapakidou, and Derri, 2004) as well as in the working of human systems - cardiovascular, respiratory, or motor (Jeffcock, 2006).

\section{METHODS}

\section{Participants}

In the research participated 89 female and male athletes from the three faculties:

I group: 35 gymnasts (Coach faculty)

II group: 37 female students (Physical education faculty)

III group: 17 students (Kinesitherapy faculty)

The researched individuals have practiced or are still practicing different kinds of sports on diverse level.

\section{Methodology}

In order to fulfill the aim of the research we used tests recommended by Damjanovska et al. (2013) and tried out in rhythmic gymnastics (Damjanovska et al., 2015).

Four tests for assessment of coordination in rhythm were used and the results were recorded in number of cycles made in 20 seconds:

Frontal kicking with legs and arms on the wall.

On the floor in length of $20 \mathrm{~cm}$ from the wall, is marked a line, behind which stands the performer in upright position, turned with her face to the wall. Also, in $20 \mathrm{~cm}$ height is drawn a line. Hands of subjects are raised at a right angle in the height of the shoulders. Within 20 seconds, the performer should do the following actions: with his right foot hits the wall over the line, lowers his right foot on the floor, then takes a shot with his left foot, lowers the leg down to the floor. Then follows alternately hits with hands to the wall as follows: right hand, after that with the left hand and again with the right one. That is one cycle of movement. The next cycle of movement starts with a hit of his left foot to the wall, and then with the right foot continuing with alternately hitting the left, right, left hand to the wall. Cycles of movements is performed by the end of 20 seconds. The test is executed three times, the number of the best performed cycles is recorded. Practicing is not allowed. (Damjanovska et al., 2013, p. 282) 
Jumps in four squares.

In the floor are painted four squares of the same dimension, $40 \times 40 \mathrm{~cm}$, spaced from each other in $5 \mathrm{~cm}$. The performer stands in an upright position, with free slumped hands beside the body, in the right lower square. The movement starts with a jump of the right foot into the right upper square, jumping with the left foot into the left upper square, starting with the right foot in the lower left square and taking three steps (right, left, right foot), after the performed three steps, with his left foot jumps in the left upper square, with the right foot jumps in the top right square, and starting with the left foot in the lower right square takes three steps (left, right, left foot). This makes one cycle of movements. The test is executed three times, the number of the best performed cycles in 20 seconds is recorded. Practicing is not allowed. (Damjanovska et al., 2013, p. 282)

\section{Crossover jumps in four squares.}

Is the same as the previous test, but here the movement starts with left foot jump in the left upper square, and with his right foot in the right upper square, with the left leg jump in the lower left square is performed three steps (left, right, left foot). Then the movement starts with the right foot jump in the top right square, then with left foot jump in the left upper square and starting with the right foot in the lower right square is performed three steps (right, left, right foot). This makes one cycle of movement. The test is executed three times, the number of the best cycles in 20 seconds is recorded. Practicing is not allowed. (Damjanovska et al., 2013, p. 282)

\section{Kicking with legs and arms (in a corner).}

This test is performed in the corner of a room. On the left and right side of the floor, in height and distance from the floor, are marked lines with a length of $20 \mathrm{~cm}$. Respondent in upright position, with arms raised to the level of the shoulders, stands on the marked place. With the right side of the body the hits are performed to the right side wall, while with left side of the body to the left side of the wall. But the movements are performed as follows: the respondent with the left foot hits the left wall above the line and lowers the leg on the floor, with his right hand hits the right wall at the height of the chests, separates the arm from the wall, with his left hand, at the height of the chests, hits two consecutive times in the left wall, separates the left hand from the wall, with the right foot strikes the right wall and lowers the leg on the floor. This makes one cycle of movement. Respondent, starting with hitting with his left foot into the left wall opens the next cycle of movement. The test is executed three times, the number of the best performed cycles in 20 seconds is recorded. Practicing is not allowed. (Damjanovska et al., 2013, p. 282)

Each test was executed three times. We allowed for a short elaboration of the movements in the beginning. However, we did not let the subjects learn them well. The results from all tests were recorded in a preliminarily prepared individual form for each participant in the research. In the end, the best achievement was highlighted.

The tests we chose are characterized with general music-rhythmical structure, the movements involved are five-three with a bigger amplitude and two with a smaller one. They are subjected to the same metro-rhythm and are counted as one/two, one-two/ three, with two four time.

Math-statistical methods:

Variation analysis of the results from the research aimed at establishing the statistically significant relations between the variables of coordination in rhythm.

All statistical analyses were performed with the use of SPSS 19.

\section{RESULTS}

Tables 1, 2 and 3 present the results from the research and the variation analysis. The average number of cycles performed for each of the tests ranges from 7.09 to 10.6 with the students from I group (Coach faculty); from 4.41 to 8.24 with the students from II group (Physical education faculty); and from 5.76 to 10 with III group (Kinesitherapy). The variation of the values is relatively high in all the tests because the coefficient of variation is over $10 \%$. The values have a normal distribution. The coefficients of asymmetry and excess constitute a sufficient premise for this conclusion. The values of the range (R) are similar with the exception of the test Frontal kicking with legs and arms on the wall, where $\mathrm{R}=15$ for I group; test Jumps in four squares $\mathrm{R}=11$ for II group, and 
test Kicking with legs and arms (in a corner) $\mathrm{R}=10$ for III group. The average values of the results from the tests are higher for I group, especially regarding the tests performed with arms and legs - Frontal kicking with legs and arms on the wall $(x=10.20$, $\mathrm{x}=4.41,=5.76$, for the three groups and Kicking with legs and arms (in a corner) ( $\mathrm{x}=10.6, \mathrm{x}=8.24, \mathrm{x}=10.00)$. The mean values of the results from tests 2 and 3 (Jumps in four squares and Crossover jumps in four squares) are not characterized with big differences both within the groups and between the groups. We should pay attention to the following values: $X \min =0$, in test 3 for II group and Xmin=1, in the same test for
I group. The students from I and II group are within the range of the normal students' age but the bigger age values in II group are due to the part-time students who joined the research. They usually begin their education at a later age, or this is their second university degree. Sports experience is an index which generally influences the rhythmical abilities of the students. Due to the fact that these abilities are dependent on the individual rhythmical abilities, and they have been developed and perfected in diverse ways specific for the different sports disciplines, the result Xmin=0 for II and III group could not have influenced the research so much.

Table 1

Variation analysis of the results from the research among students from the Coach faculty

\begin{tabular}{|c|c|c|c|c|c|c|c|c|c|c|c|}
\hline & Index & n & Xmin & Xmax & $\mathbf{R}$ & $\bar{X}$ & $\mu_{\mathrm{x}}^{-}$ & S & V & As & Ex \\
\hline 1 & $\begin{array}{l}\text { Frontal kicking with legs } \\
\text { and arms on the wall }\end{array}$ & 35 & 5 & 20 & 15 & 10,20 & 0,53 & 3,16 & 30,98 & 1,027 & 1,698 \\
\hline 2 & Jumps in four squares & 35 & 3 & 11 & 8 & 7,23 & 0,32 & 1,90 & 26,22 & $-0,294$ & 0,174 \\
\hline 3 & Crossover jumps in four squares & 35 & 1 & 11 & 10 & 7,09 & 0,35 & 2,09 & 29,51 & $-0,509$ & 0,702 \\
\hline 4 & $\begin{array}{l}\text { Kicking with legs and arms } \\
\text { (in a corner) }\end{array}$ & 35 & 5 & 16 & 11 & 10,60 & 0,51 & 3,03 & 28,59 & $-0,057$ & $-0,622$ \\
\hline 5 & Age & 35 & 19 & 24 & 5 & 20,91 & 0,24 & 1,40 & 6,70 & 0,161 & $-0,908$ \\
\hline 6 & Sports experience & 35 & 7 & 18 & 11 & 13,17 & 0,44 & 2,60 & 19,70 & $-0,575$ & $-0,134$ \\
\hline 7 & Height & 35 & 158 & 180 & 22 & 167,94 & 0,79 & 4,70 & 2,80 & 0,201 & 0,461 \\
\hline 8 & Weight & 35 & 45 & 63 & 18 & 54,66 & 0,67 & 3,96 & 7,24 & $-0,144$ & 0,305 \\
\hline
\end{tabular}

Table 2

Variation analysis of the results from the research among students from Physical education faculty

\begin{tabular}{|c|c|c|c|c|c|c|c|c|c|c|c|}
\hline & Index & $\mathbf{n}$ & Xmin & Xmax & $\mathbf{R}$ & $\bar{X}$ & $\mu_{\mathrm{x}}$ & $\mathbf{S}$ & V & As & Ex \\
\hline 1 & $\begin{array}{l}\text { Frontal kicking with legs } \\
\text { and arms on the wall }\end{array}$ & 37 & 2 & 13 & 11 & 4,41 & 0,34 & 2,05 & 46,42 & 2,350 & 7,910 \\
\hline 2 & Jumps in four squares & 37 & 4 & 11 & 7 & 6,89 & 0,28 & 1,70 & 24,62 & 0,431 & 0,142 \\
\hline 3 & Crossover jumps in four squares & 37 & 0 & 11 & 11 & 6,43 & 0,42 & 2,54 & 39,56 & $-0,377$ & 0,487 \\
\hline 4 & $\begin{array}{l}\text { Kicking with legs and arms } \\
\text { (in a corner) }\end{array}$ & 37 & 1 & 14 & 13 & 8,24 & 0,55 & 3,35 & 40,59 & $-0,360$ & $-0,146$ \\
\hline 5 & Age & 37 & 18 & 38 & 20 & 21,22 & 0,46 & 2,91 & 13,72 & 4,941 & 28,942 \\
\hline 6 & Sports experience & 37 & 0 & 13 & 13 & 6,10 & 0,67 & 4,31 & 70,59 & $-0,094$ & $-1,384$ \\
\hline 7 & Height & 37 & 154 & 185 & 31 & 167,73 & 1,15 & 7,02 & 4,18 & 0,559 & 0,064 \\
\hline 8 & Weight & 37 & 45 & 75 & 30 & 57,59 & 1,25 & 7,59 & 13,17 & 0,610 & $-0,146$ \\
\hline
\end{tabular}


Table 3

Variation analysis of the results from the research among students from Kinesitherapy faculty

\begin{tabular}{|c|c|c|c|c|c|c|c|c|c|c|c|}
\hline & Index & $\mathrm{n}$ & Xmin & Xmax & $\mathbf{R}$ & $\bar{X}$ & $\mu_{\mathrm{x}}^{-}$ & $S$ & $\mathrm{v}$ & As & Ex \\
\hline 1 & $\begin{array}{l}\text { Frontal kicking with legs } \\
\text { and arms on the wall }\end{array}$ & 17 & 3 & 10 & 7 & 5,76 & 0,49 & 2,02 & 35,00 & 0,831 & 0,060 \\
\hline 2 & Jumps in four squares & 17 & 5 & 12 & 7 & 7,82 & 0,51 & 2,10 & 26,84 & 0,494 & $-0,299$ \\
\hline 3 & Crossover jumps in four squares & 17 & 3 & 10 & 7 & 6,71 & 0,51 & 2,09 & 31,07 & $-0,213$ & $-1,097$ \\
\hline 4 & $\begin{array}{l}\text { Kicking with legs and arms } \\
\text { (in a corner) }\end{array}$ & 17 & 5 & 15 & 10 & 10,00 & 0,61 & 2,50 & 25,00 & 0,000 & 0,325 \\
\hline 5 & Age & 17 & 18 & 30 & 12 & 20,12 & 0,68 & 2,78 & 13,82 & 3,122 & 10,978 \\
\hline 6 & Sports experience & 17 & 0 & 14 & 14 & 5,59 & 1,10 & 4,54 & 81,25 & 0,476 & $-0,648$ \\
\hline 7 & Height & 17 & 170 & 193 & 23 & 180,00 & 1,62 & 6,68 & 3,71 & 0,716 & $-0,424$ \\
\hline 8 & Weight & 17 & 62 & 88 & 26 & 73,76 & 2,18 & 9,00 & 12,20 & 0,271 & $-1,519$ \\
\hline
\end{tabular}

\section{DISCUSSION}

The results from the three groups of researched individuals show an interesting trend, namely that forming the groups on the base of the faculty they study at is a good starting reasoning point. Certain abilities can be defined, related to the kinds of sports the students practice and their rhythmical abilities.

The rhythmical abilities of the sports students are generally related to the following factors:

- The nature of the sports discipline practiced and its requirements for coordination of the body's rhythm of movement and the apparatus used (ball, clubs, ribbon, hoop, rope, etc.);

- One or several partners during different interactions (team play, as basketball or volleyball, acrobatics, as pyramids and figures);

- Musical accompaniment (rhythmic and aesthetic gymnastics, synchronized swimming).

Most of the students from I group major in gymnastics - rhythmic, artistic, aesthetic and aerobics.

The exercises in the different types of gymnastics are generally predetermined as a motor model and the execution is related to the uniformity of the body's rhythm, the handling of the apparatuses and the musical accompaniment. The music means of expres- sion (tempo, rhythm, dynamics, melody) are the main measure unit for rhythmic mastery and execution of the gymnastics movements.

The perfected skills should be performed with body with slow and graceful movements (dancing steps, turns) while following the melody line of the musical accompaniment and at the same time with dynamic movements with the apparatus (spins with rope, snakes with ribbon, asymmetric movements with clubs) according to the accents of the music. This was in the base of the results from the above-mentioned tests. The execution of fast movements with the body and slow, amplitude movements with the apparatus is also a possible combination.

The achieved results from the tests, performed with feet and supportive free movement of the arms, are a manifestation of what is known as acquisition of rhythmical elements - the ability to display rhythm through a motor activity at externally determined rhythm by a musical accompaniment. Most often these are various gymnastics or dancing steps according to the aforesaid musical accompaniment where the main activity is performed with feet.

The tests 1 and 4 are performed with arms and feet and the sequence of these movements in the music time do not trouble the gymnasts. The present study confirms the definition given by Hadjiev et al., (2011, pp. 106): 
The rhythmical ability is most often manifested in rhythmic and artistic gymnastics and aerobics where the competitors perform their routines with musical accompaniment. Each gymnastics exercise and every routine have their specific rhythm of execution related to the gymnasts' kinematic and dynamic abilities.

The rhythmical abilities of the female players from II and III groups, who practice other sports, are perfected in different conditions. The constantly changing environment in team games, the collaboration with the teammates, and the absence of musical accompaniment with strictly defined function, place the researched groups in a totally different situation. Their rhythmical abilities correspond to the motor activity they practice, depending on the individual inner rhythm of the body, but differ in their manifestation from the rhythmical abilities of the gymnasts.

\section{CONCLUSION}

The results from the research confirm the fact that the sports students in the three faculties possess good rhythmical abilities. The better achievements of the gymnastics students in the tests performed with feet and legs confirm the conclusion that the natural rhythmical abilities can be further developed and perfected with the help of the specific means of the particular discipline. The major factor turns out to the music as an outer reference point and a measurement of the exact duration of the different phases of the exercises. The perfection of rhythmical abilities should be accomplished with musical accompaniment regardless of the nature of the motor activity one practices.

The movements in the applied tests are subjected to strictly defined rhythmical structure and could be an exact quantitative measurement of rhythmical abilities.

\section{REFERENCES}

Damjanovska, M., Gontarev, S., and Radisavljevic, L. (2013). Determination of measurement characteristics for rhythmic skills assessment tests. Conference proceedings, Effects of Physical Activity Application to Anthropological Status with Children, Youth and Adults. Beograd, december, 281-287.

Damjanovska, M., Gontarev, S., Rhedzepi, A., and Gantcheva, G. (2015). Comparing reliability and validity of some tests with classic and image model of assessment rhythmic ability. Sborník příspěvků z mezinárodní vědecké conference. Evropské Pedagogické Fórum, Hradec Králové, Česká republika. november, 212-217.

Jeffcock, D. (Director). (2006). How music works with Howard Goodall - 02 Rhythm [Motion Picture].

Hadjiev, N., Andonov, K., Dobrev, D., and Petrov, V. (2011). Gymnastics - physical preparation. Sofia : NSA Press.

Mienel, Y. and Schnabell, G. (1987). Teoría del Movimiento. Buenos Aires: Stadium.

Rachev, K. (1984). Theory and methods of physical education [Textbook]. Sofia: Medicine and Physical education.

Schaal, S., Sternad, D., Osu, R., and Kawato, M. (2004). Rhythmic arm movement is not discrete. Nature Neuroscience, 7 (10), 1136-1143.

Stoikov, S. (2014). Athletics [Textbook]. NSA Press. Sofia. ISBN 978-954-718-393-3.

Zachopoulou, E., Tsapakidou, A., Derri, V. (2004). The effects of a developmentally appropriate music and movement program on motor performance. Early Childhood Research Quarterly, 19, 631-642. 